\title{
Støtte til forældre til selvmordstruede sønner og døtre - metodeovervejelser
}

\author{
Af Elene Fleischer og Anna Knudsen
}

\begin{abstract}
Flere undersøgelser ved psykiatriske hospitaler i Danmark viser, at forældre som pårørende stort set er tilfredse med tilbuddene til den selvmordstruede søn eller datter, men at de pårørende selv mangler rådgivning og støtte (Folkesundhed og Kvalitetsudvikling 2011, Danske regioner 2010).
\end{abstract}

\begin{abstract}
Artiklen beskriver udvikling af en model, et gruppetilbud, hvor der ydes st $\varnothing$ tte og rådgivning til forældre til selvmordstruede $s \varnothing n n e r$ og døtre. En model, der håndterer de mange udfordringer, forældre står over for efter en søn eller datters selvmordsfors $\emptyset$ g. De adspurgte forældre gav udtryk for, at st $\varnothing t t e n$ til deres barn eller ung efter selvmordsfors $\emptyset \mathrm{g}$ var tilstrækkelig, men de oplevede en mangel på effektiv støtte til sig selv og familien som helhed. Behandlerteamet (forfatterne til denne artikel, der også har været de primære gruppeledere de sidste tre år) udviklede en model for samtale og intervention i mindre grupper (4-8). Her kunne forældrene dele deres bekymringer, frustrationer, vrede og angst med andre ligestillede forældre. Gruppesessionerne blev ledet af to fagfolk, der også involverede psykoedukation med fokus på behandling af depression, borderline, tilbagefald og kommunikationsm $\varnothing$ nstre. Det var nødvendigt for gruppelederne at udvikle en omkostningslav model for støtte og rådgivning. Det var derfor en forudsætning, at modellen kunne anvendes af fagprofessionelle frivillige. Modellen har vist sig effektiv til at minimere frafald til gruppesamlingerne, og forældrene udtrykte generelt en højere grad af selvtillid undervejs og ved afslutningen af forløbet, end de havde i begyndelsen. Det formodes, at de profylaktiske indsatser målrettet unges selvmordsadfærd vil være mere effektive, hvis disse kombineres med rådgivning og støtte til forældrene.
\end{abstract}

The idea of this project was to clarify to what extent parents of suicidal children and adolescents need support to handle the many challenges they must confront following a child or adolescents suicide attempt. The parents generally expressed that the support for their child or adolescent after the suicide attempt was adequate and sufficient; however, they felt a lack of effective support for themselves. The research group developed a model for group therapy in smaller groups (4-8), where the parents could share their anxieties, frustrations, anger, and remorse with like-minded persons. The sessions, conducted by two professionals, also involved psycho-education focusing on treatment of depression, borderline, recidivism, and communication patterns. It was imperative for the therapists to develop a cost effective model for this specific kind of treatment, which was achieved by involving skilled volunteers. The model has shown its effectiveness in minimizing the drop-out rate of parents and most parents expressed a much higher degree of selfconfidence. The prophylactic efforts towards suicidal behavior among younger people probably are more effective if combined with counseling and support to the involved parents.

LEVERT: $\quad 30 / 11-11$ REVIDERT: $\quad 19 / 7-12$ AKSEPTERT: $19 / 7-12$
Hensigten var at udvikle et tilbud til pårørende med redskaber, som de ber $\varnothing$ rte forældre kunne se værdien af. Formidlingen skulle sikre at flest mulige pårørende i målgruppen blev bekendt med tilbuddet. Desuden skulle behandlerne i den offentlige sektor også have tillid til at dette nye pårørendetilbud kunne være et nyttigt supplement til den specifikke, målrettede behandling de selv ydede den selvmordstruede. Derudover skulle modellen være så stærk, at frafald blandt forældrene blev minimeret.

Tilbuddet er gennemf $\varnothing \mathrm{rt}$ i et samarbejde mellem faglig leder i den frivillige organisation NEFOS (Netværket for Selvmordsramte), Center for Selvmordsforebyggelse i Region Nordjylland (CFS) og Klinik og KompetenceCenter for Selvmordsforebyggelse i Region Syddanmark (KKCS).

Modellen er afprøvet som pilotprojekt med tre grupper - i alt 21 personer - i Region Nordjylland (2007-2009), herefter justeret og gennemf $\varnothing$ rt med seks grupper - i alt 37 personer i Region Syddanmark (2009-2011). Gruppesamtalerne er afviklet efter samme grundmodel, dog tilpasset i takt med erfaringerne.

\section{Ét selvmordsforsøg - mange berørte}

Det vides ikke præcis hvor mange børn og unge der hvert år fors $\varnothing$ ger selvmord i Danmark. Center for Selvmordsforskning (2010) skønner at 2.200 børn og unge under 30 år hvert år truer med selvmord eller udfører et eller flere selvmordsfors $\varnothing$ g. Det betyder, at mange forældre er direkte ber $\varnothing$ rt som pår $\varnothing$ rende. Forældrene rammes hårdt af deres børns selvmordsfors $\varnothing \mathrm{g}$, de kommer i krise, bliver rådvilde, og de mister tilliden til både barnet og sig selv (Søndergaard 2008).

Den selvmordstruede kan i Danmark få hjælp flere steder. Men behandlingstilbuddene i psykiatrien, forebyggelsescentrene eller kommunerne er ikke tilpasset hele familien, fokus er primært og hoved- sagelig på den selvmordstruede. Forældre til selvmordstruede inddrages i begrænset omfang i behandlingstilbudet. Og når det sker, er der ikke opmærksomhed på, hvordan det er at være forældre til en selvmordstruet s $\varnothing$ n eller datter (uanset alder) med de problemer det medfører for de forskellige familiemedlemmer, herunder også stigmatiseringen fra omverdenen (Gerlach 2008, Jørgensen 2011).

\section{Forebyggelse}

Formodentlig vil en del familier med selvmordstruede unge have brug for professionel hjælp. Det formodes, at en profylaktisk indsats rettet mod børn og unges selvmordsfors $\varnothing$ g måske vil være mere virkningsfuld, hvis indsatsen suppleres med aktiv rådgivning og st $\varnothing$ tte til forældrene og eventuelle søskende. Det er via inddragelse af forældrene, at der kan gives st $\varnothing$ tte og rådgivning i forhold til hele familiens trivsel, herunder også en forebyggende indsats i forhold til evt. søskendes mistrivsel (Søndergaard 2008). I forhold til forældrene er det også muligt at fokusere og dermed måske også ændre dysfunktionelle kommunikationsmønstre i familierne (Fleischer 2000, Søndergaard 2008, Jakobsen 2011).

\section{Oprettelse af et pårørende-} tilbud - metode og model for samtalegrupper

I perioden fra 2004 til 2007 ydede NEFOS alene rådgivning og st $\varnothing t t e$ som individuelle- og parsamtaler, men forældrene efterspurgte andre forældre, der også havde tilsvarende oplevelser i deres familie med en søn eller datter, der forsøgte selvmord.

I de seneste fem år har den frivillige organisation NEFOS, udviklet en model for samtalegrupper bygget op omkring erfaringsdeling og psykoedukation under hensyntagen til de eksakte problemstillinger, som forældrene til de selvmordstruede unge står med. 
NEFOS har i projektperioden (2007-2011) rekrutteret professionelle rådgivere (både lønnede og ulønnede) til varetagelse af både individuelle- og gruppesamtaler med de pårørende til selvmordstruede børn og unge.

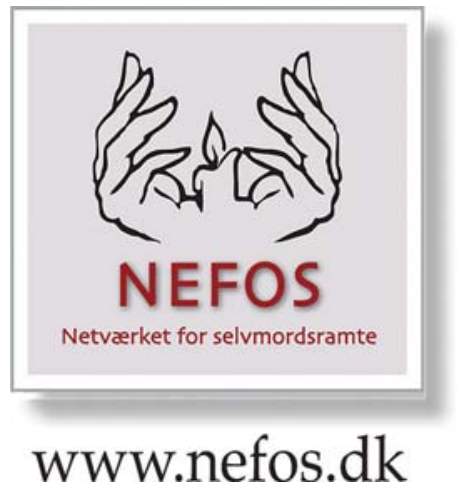

\section{Tilnaerming}

I samtalegruppe-tilbuddet gøres der brug af forskellige metodiske tilnærminge. Gruppelederne g $\varnothing \mathrm{r}$ brug af både deres personlige livserfaringer og en faglighed, hvor de har kendskab til virkningen af psykoedukation og til konkret støtte og rådgivning i krisesituationer. De berørte og ofte usikre forældre mødes i en ligeværdig dialog, ligesom den betydningsfulde interaktion imellem gruppedeltagerne prioriteres og er central. Forældrene er som pårørende i gruppeledernes fokus. I gruppesamtalen er den selvmordstruede søn eller datter ikke det centrale, det er det faktum, at de er forældre til en selvmordstruet person. Hensigten er at se den enkelte forælder og se de belastninger, vedkommende står med som følge af angsten for nye selvmordsfors $\varnothing \mathrm{g}$, og ud fra denne iagttagelse yde st $\varnothing t t e$ og rådgivning til forælderen, og dermed også til st $\varnothing$ tte for familien som helhed.

Der tages udgangspunkt i den her og nu-situation, som hver enkelt gruppemedlem kommer med. De er alle aktivt deltagende i en erfaringsudveksling, mens to gruppeledere skaber en tryg ramme, der giver mulighed for refleksion og nyfortolkning af de fortalte erfaringer. Der suppleres med egentlig psykoedukation (Jørgensen 2011) om forskellige grundlæggende elementer som fx: Depression og relevant behandling af depression (Gerlach 2006). Emotionel ustabil per- sonlighedsstruktur, borderline-type og behandlingsmuligheder (Garde \& Gerlach 2006). Recidivrisiko (Benjaminsen 2005). Kønsspecifikke forskelle i mestringsstrategier, krisereaktioner og oplevelsen af ensomhedsformer (Fleischer 2009, Jacobsen 2009). Forskellige former for kommunikationsstrategier, herunder anvendelsen af tavshed (Fleischer 2000).

\section{Bæredygtig i alle henseender}

Udfordringen ved oprettelsen af pår $\varnothing$ rendetilbuddet bestod i løsningen af følgende spørgsmål:

- Hvorledes rekrutteres forældre til selvmordstruede?

- Hvorledes opbygges en model, der i videst muligt omfang forhindrer frafald?

- Hvorledes gives og afsluttes et kortvarende tilbud på en måde, der st $\varnothing$ tter forældrene og giver dem tiltro til egne ressourcer og mestringsevner.

\section{Rekruttering}

\section{Formidling og implementering $i$} Region Syddanmark

Klinik og Kompetencecenter for Selvmordsforebyggelse (KKCS) i Region Syddanmark blev oprettet i 1991. I 2008 indgik NEFOS og KKCS et uformelt samarbejde om igangsæettelse af samtalegrupper for forældre til unge mellem 15 og 25 år, og planlagde en bred, effektiv informationsstrategi.

Der blev opsat plakater med visitkort på sygehuses skadestuer, hospitalsafdelinger og Psykiatrisk informationscentre (Psyk-info) - hos praktiserende læger og psykologer samt i KKCS's eget venterum. Klinikkens behandlere og sekretærer videreformidler tilbuddene, når de har kontakt med selvmordstruede og deres pårørende.

\section{Tiltag, der kan minimere frafald}

\section{Visitation}

Indledende inviteres forældrene til 1-3 visiterende for-samtaler med den faglige leder i NEFOS. Her vurderes bl.a. om den enkelte er i stand til at indgå i en samtalegruppe, idet forælderen skal kunne åbne for sin egen historie og rumme de andre deltageres beskrivelser. Ved mødet oplyses om gruppens sammensætning, hvordan der arbejdes og forventningerne til den enkelte, $\mathrm{fx}$ rettigheder og pligter.

Eksklusionskriterium: Forældre sk $\varnothing n n e t$ for akut kriseramte til at deltage i gruppetilbuddet og forældre med psykiatrisk diagnose eller misbrugsproblemer, blev opfordret til at tage kontakt til egen læge for at få det rette behandlingstilbud.

\section{(Q)) Hjælp til pårørende}

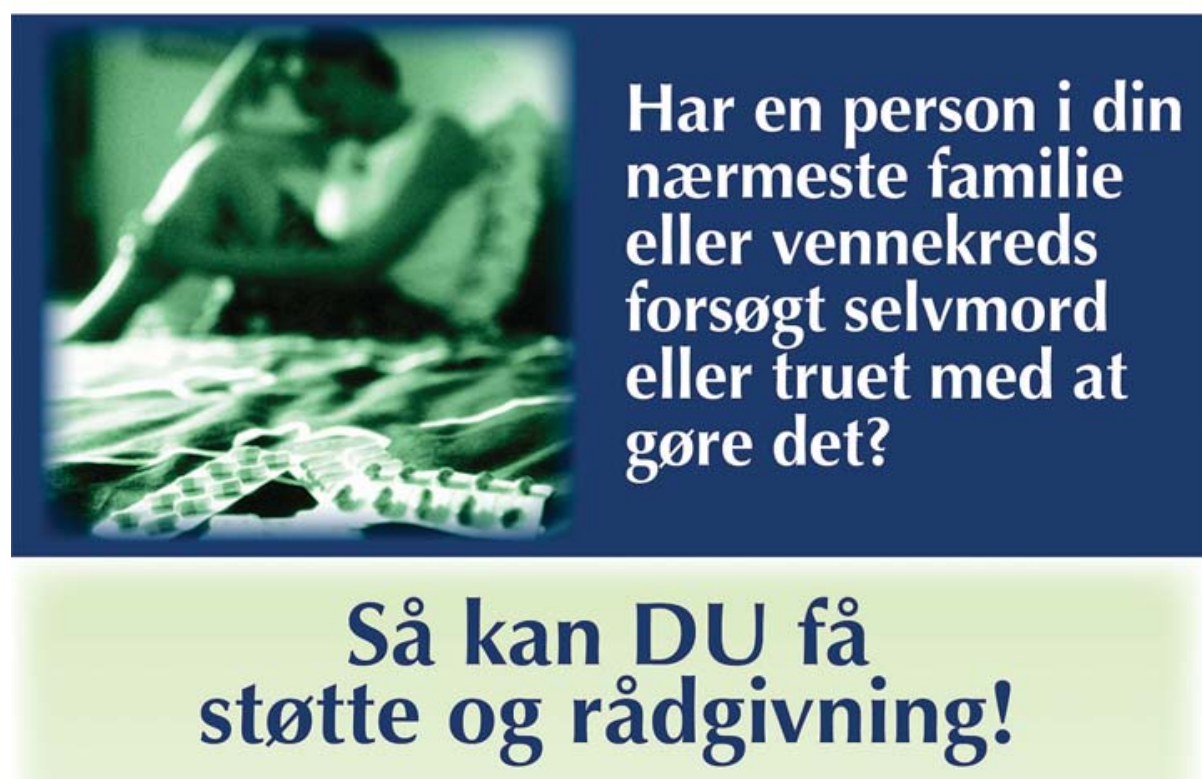


Erfaringerne viser, at ca. 4 ud af 5 forældre efterfølgende indgår i et gruppeforl $\varnothing \mathrm{b}$. I perioder med ventetid på gruppestart tilbyder NEFOS individuelle samtaler med en professionel rådgiver, indtil gruppetilbuddet kan realiseres. Der påbegyndes nye grupper to gange årligt i februar og i august.

Forældrenes alder og sociokulturelle baggrund varierer. Alderen på den selvmordstruede er typisk 13-30 år. Er der fx tale om skilsmissefamilier, hvor begge biologiske forældre og evt. nye partnere $\varnothing$ nsker at indgå i en gruppe, kommer parrene i to forskellige grupper. Familien, der har den unge boende, făr førsteprioritet.

Det tilsyneladende optimale er, at gruppemedlemmerne matches i forhold til den selvmordstruedes alder. Der kan være stor forskel på, hvilke udfordringer forældre står med, om deres barn er over eller under 18 år, om den unge har en egentlig psykisk lidelse eller om selvmordsadfærden alene kan tilskrives alment forekommende belastninger blandt unge. Ved at tilstræbe et ens grundlag фges muligheden for, at forældrene får gavn af at dele erfaringer med hinanden og af at lytte og spejle sig i andres erfaringer.

\section{Regler og ritualer}

Under for-samtalen introduceres de fire grundlæggende regler for deltagelse i gruppem $\varnothing$ derne med henblik på at skabe tryghed for det enkelte gruppemedlem, og derved modvirke frafald:

- Tavshedspligt, der også medfører, at den enkelte gruppedeltager alene præsenterer sig ved fornavn.

- Afbudspligt. Der er ikke mødepligt, men afbudspligt via mail, telefon eller sms til gruppelederen mindst 10 minutter f $\varnothing \mathrm{r}$ gruppem $\varnothing$ dets start. Begrundelsen er at imødegå automattænkning som: "Har jeg sagt eller har jeg gjort noget forkert ved det sidste møde, noget der gør, at han eller hun ikke kommer?"

- Hilseritualer: Alle hilser med håndtryk ved ankomst og afgang fra mødet. Det er positivt og tryghedsskabende at give hånd. Vi har фjenkontakt og er i hinandens fokus. En relation etableres med et goddag og afbrydes, når vi siger farvel.

- Kun gruppelederne kan stille spørgsmål til den enkelte forælder under mødet. Begrundelsen er, at den terapeutiske tilgang er grundlaget for den kommunikative alliance, ikke for privat eller personlig nysgerrighed.

Vi undlader at fokusere på personlige, private og særdeles intime temaer, der ikke er relevante for flertallet af gruppedeltagerne. Kommer temaerne frem, giver gruppeleder et tilbud til denne forælder, inden der siges farvel. Fx individuelle samtaler i NEFOS eller KKCF.

\section{Gruppestørrelse}

En samtalegruppe består af 4-8 forældre plus to professionelle gruppeleder. Evt. et par studerende eller nyansatte, som er under oplæring til gruppeleder. Gruppen mødes på hverdagsaften - to timer hver 14. dag i otte uger efterfulgt af et opfølgende møde efter tre måneder. De første tre mødegange er gruppen åben for evt. nye forældre. Herefter lukkes gruppen for nye deltagere.

\section{Rammer og struktur}

Kaffe, te, vand, frugt, chokolade og småkager står på bordet.

Den første time er en runde, hvor hvert enkelt gruppemedlem fortæller, hvad vedkommende her og nu er optaget af og gerne vil have belyst og drøftet i gruppen. Den ene gruppeleder er primært udforskende i dialogen med gruppedeltagerne, den anden er primært referent. Under runden skriver gruppelederne stikord på tavlen ud fra det de hører. Efter 50 minutter er der pause. Gruppelederne forlader lokalet, og forældrene har mulighed for at være sociale. Under pausen vurderer gruppelederne, hvilke temaer og hvilket problemfelt eller individuel belastning der skal uddybes i de resterende 50 minutter.

\section{Den gode afslutning}

Ved det sjette gruppem $\varnothing$ de taler vi om, at der nu kun er to gange tilbage plus en opfølgningsgang. Forældrene opfordres til at mærke efter, om de er klar til at slippe gruppen og klare forældrerollen uden denne ramme - eller de er utrygge, fordi deres $s \varnothing \mathrm{n} /$ datter fortsat er akut selvmordstruet? Oplever en eller flere forældre et behov, tilbydes de at deltage i et nyt gruppeforl $\varnothing b$.

\section{Gruppeprocessens dynamik}

Undervejs i de forskellige grupper iagttages flere basale dynamikker. Overordnet kan gruppeprocesserne opdeles i følgende tre faser:

Opstartsfasen præges af utryghed og anspændt stilhed. Det er tydeligt, at forskelle i gruppedeltagernes baggrund og oplevelser fremkalder usikkerhed. Der er megen gråd og stilhed med en massiv forventning til gruppeledernes input. Også pauserne præges af stilhed. Der gives dog åbent udtryk i gruppen for lettelse ved ikke at være alene om at føle og tænke, som de g $\varnothing \mathrm{r}$ i forbindelse med deres selvmordstruede $s \varnothing n$ eller datter.

Mellemfasen præges af tillid og tryghed i gruppen. Gråd og latter veksler, og anspændtheden forsvinder jo mere åbenhed, der opbygges. Det går an at være sårbar og føle sig ensom. Interaktionen mellem deltagerne фges, og pauserne benyttes til både smalltalk og fortsat udveksling om emnerne i gruppen.

Slutfasen præges af tryghed i gruppen, den enkelte vedkender sig sine behov. Der er ikke modstand mod eller usikkerhed ved, at gruppelederne begynder at lægge op til afslutning. Der er enighed i gruppen om, at der er godt med et konkret tidspunkt for opf $\varnothing$ lgningsm $\varnothing$ det ca. tre måneder senere.

\section{Diskussion}

Udgangspunktet var at udvikle og etablere en bæredygtig model i en frivillig organisation, hvor fagprofessionelle giver et målrettet tilbud til forældrene til selvmordstruede sønner og døtre. Ved at spørge forældrene er dette tilsyneladende lykkedes. Men om den bedring i den mentale tilstand, som forældrene tilskriver deltagelsen i samtalegruppen, også ville være kommet med tiden og det, at deres søn eller datter har fået behandling, ved vi reelt ikke noget om. 
Erfaringer fra Region Syddanmark viser, at den strategisk målrettede og synlige information virker, så de pårørende har fundet frem til tilbuddet. Annoncering i dagspressen og på internettet har ikke på samme måde givet resultat. At den strategiske og målrettede information virker, hænger utvivlsomt sammen med, at personalet omkring den selvmordstruede bruger tid på at motivere og oplyse de pårørende om tilbuddet.

I pilotprojektet i Aalborg blev der inkluderet forældre, som måske ikke var parate til et gruppetilbud og derfor faldt fra. Dette er undgået i Region Syddanmark, hvor der nu gives op til fem individuelle samtaler forud for samtalegruppetilbuddet. Ligeledes er de fire grupperegler basis i fastholdelsesstrategien. Glemmer en deltager at melde afbud, ringer en af gruppelederne til vedkommende. Derved er det blevet synliggjort for alle gruppemedlemmer, at de har betydning, og deres deltagelse er værdifuld for hele gruppen. Strukturen har medført, at forældrene oplever sig set, hørt og beskyttet i et fællesskab, og derfor også klarer at blive udfordret. En høj mødeprocent gennem de sidste tre år vidner om, at intentionerne om fastholdelse er lykkedes i Region Syddanmark, hvor frafald ligger på under $10 \%$.

En særlig udfordring for både forældre og gruppelederne er, hvis forældregruppen både består af forældre til sønner eller døtre, der tilh $\varnothing$ rer psykiatriens kernegruppe (pt. med skizofreni eller tunge misbrugsproblemer), og forældre til unge, der har handlet suicidalt aff $\varnothing \mathrm{dt}$ af belastninger ved mobning og/eller kærestesorger. Det optimale for både forældre og gruppeleder vil sandsynligvis være at matche forældre med $s \varnothing$ nner og døtre med samme form for psykiske og eller psykiatriske baggrund.

Blandede grupper kan medf $\varnothing$ re angst blandt de forældre, der ikke har en $s \varnothing n$ eller datter med en psykiatrisk diagnose, og det bliver formodentlig også sværere at spejle sig i de andres erfaringer og psykiske belastninger.
Der er opmærksomhed på, at der er forskelle i kommunikationen mellem familiemedlemmerne, hvis det drejer sig om en ung med teenageradfærd suppleret med selvmordsfors $\varnothing \mathrm{g}$ og/eller selvmordstruede adfærd, eller hvis vedkommende har en psykiatrisk sygdom i kombinationen med selvmordshandlingen. Dog kan blandede grupper også give håb for de forældre, der ikke har et barn med en psykiatrisk diagnose. Det ser ud til, at forældre til sønner og d $\varnothing$ tre med diagnoser som moderat depression og/eller emotionel ustabil personlighedsforstyrrelse af bordeline-typen, oplever det indsigtsgivende at kunne spejle sig i andre forældres mestring i hverdagen.

Det ser ikke ud til, at barnets alder og køn stiller særlige krav til forældre eller gruppeleder. Tværtimod kan forældrene få indsigt, når forældrerolle og behandlingstiltag opsplittes ved barnets fyldte attende år.

Det ser ud til, at afslutningsproceduren medfører, at forældre er forberedte på egne reaktioner. Det er trygt at være forberedt og kende muligheden for at kunne deltage i en anden gruppe og at kunne se frem til, når gruppen mødes og følger op efter tre måneder.

Det uformelle samarbejde mellem fagpersoner fra hhv. det offentlige system og en frivillig organisation har således med støtte fra bl.a. Socialministeriets projektmidler gjort det muligt at udvikle et lav $\varnothing$ konomisk og fagligt bæredygtigt tilbud, der formodentligt tilgodeser behovet for rådgivning og st $\varnothing t t e$ hos forældre som pårørende til selvmordstruede sønner og døtre i Region Syddanmark.

\section{Etiske aspekter:}

Der er optimalt hensyntagen til, at forældre er belastede og i krise. Ved svære psykologiske belastninger henvises til relevant lægelig eller psykologisk behandling.

\section{Interessekonflikter: Ingen.}

\section{Økonomisk støtte:}

Projektet er st $\varnothing$ ttet af: TrygFonden, Odense Kommune, Socialministeriet m.fl.

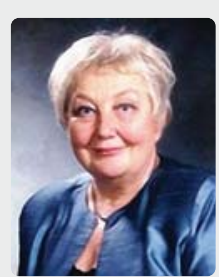
Elene Fleischer, ph.d. er daglig leder i Forskning og Forebyggelse i Odense og formand for landsforeningen NEFOS, Netværket for Selvmordsramte, www.NEFOS.dk. Hun var 1998-1999 ansat i lektorat ved Troms $\varnothing$ Høiskole og 2000-2009 som specialkonsulent ved Nordnorsk psykiatriske forskningscenter (NNPF) Troms $\varnothing$. Hun var i 20002009 ansat ved Center for Selvmordsforebyggelse, Region Nordjylland, som projektleder på indsatsprojektet: Forebyggelse af ældre menneskers selvmord.

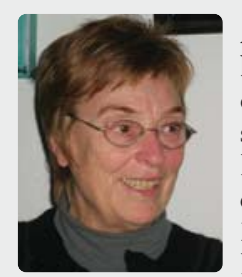

Anna F. Knudsen er psykiater og leder af Klinik og Kompetencecenter for selvmordsforebyggelse, Psykiatrien i Region Syddanmark. Hun var 19932001 ansat som adm. overlæge i Psykiatrien i Troms $\varnothing$.

\section{Referencer}

Benjaminsen, S. (2005). Selvmordsfors $\phi$ g, Unders $\phi$ gelse og Behandling. Kvalitetsprojekt. Modelprojekt nr. 21, Odense Universitetshospital.

Center for Selvmordsforskning (2011). Register for selvmordsfors $\phi \mathrm{g} 2009$. Statistikbank. DK. http://www.selvmordsforskning.dk

Fleischer, E. (2000). Den talende Tavshed. Selvmord og selvmordsfors $\phi \mathrm{g}$ som talehandling (oprindelig ph.d.-afhandling 1997): Odense Universitetsforlag.

Fleischer, E. (2009). Ensomheden - selvmordets f $₫$ lgesvend. Månedsskrift for praktisk lægegerning. Nr. 4.

Folkesundhed og Kvalitetsudvikling (2011). Patienter og pår $\phi$ rende har ordet. Tilfredshedsunders $\phi$ gelse af distriktspsykiatrien 2010.

Danske Regioner (2010): http://www.regioner. $\mathrm{dk} /$ Publikationer/Psykiatri/ Tilfredshedsunders $\phi$ gelse +i+distriktspsykiatrien+2010.aspx

Gerlach, J. (red.). (2006). Depression. København: Psykiatrifondens Forlag.

Gerlach, J. (red.). (2008). Pårørende - råd og vejledning til pårorende til mennesker med psykisk sygdom. København: Psykiatrifondens Forlag.

Jacobsen, B. (2009). Livets dilemmaer. København: Hans Reitzels Forlag.

Jakobsen, I.S. et al. (2011). Differences Between Youth with a Single Suicide Attempt and Repeaters Regarding Their and Their Parents History of Psychiatric Illness. Journal: Archives of Suicide Research, Volume 15, Issue 3, July 2011, p. 265-276.

Jørgensen, C. (2011). Pårørende har ret til psykoedukation - interview med professor i psykiatri Merete Nordentoft. Danmark: SIND bladet 2012, 01

Søndergaard, P.S. (2008). Skrig \& fred - om selvmordsfors $\phi$ g blandt unge. Aarhus: Turbine. 